This Journal is available in Telkom University online Journals

Jurnal Manajemen Indonesia

Journal homepage: journals.telkomuniversity.ac.id/ijm

\title{
The Effect of Financial Policy, Managerial Ownership, Profitability, and Company Size on Company Value in Automotive and Component Sub-Sector Companies Registered in Indonesia Stock Exchange Period 2014-2018
}

\author{
Tieka Trikartika Gustyana ${ }^{1}$, Ramadhan. Alfian Candra ${ }^{2,}$ and Dewi. Andrieta Shintia ${ }^{3}$, Nugraha ${ }^{4}$ \\ ${ }^{1,4}$ Fakultas Ekonomi dan Bisnis: Universitas Pendidikan Indonesia, Bandung, Indonesia \\ ${ }^{2,3}$ Fakultas Ekonomi dan Bisnis:Telkom University, Bandung, Indonesia
}

\begin{abstract}
The aim of each company is to increase company value which can maximize shareholders' wealth. The factors that can affect the company value are financial policies consisting of investment decisions, financial leverage and dividend policies. In addition to financial policy, there are other factors that can affect a company's value, namely managerial ownership, profitability, and company size. Therefore, this study aimed to examine the effect of financial policy, managerial ownership, profitability, and company size on company value in the automotive and component sub-sector companies registered in Indonesia Stock Exchange in 2014-2018. The data analysis techniques used in this study were multiple linear regression analysis and hypothesis testing using $t$ test, F test, and coefficient of determination. The result shows that partially investment decisions, dividend policy, managerial ownership, and company size had no effect on company value, while financial leverage and profitability had effect on company value. Simultaneously investment decisions, financial leverage, dividend policy, managerial ownership, profitability, and company size had effect on company value.
\end{abstract}

Keywords - Financial Policy; Managerial Ownership; Profitability; Company Size; Company Value.

\begin{abstract}
Abstrak
Tujuan setiap perusahaan adalah meningkatkan nilai perusahaan yang dapat memaksimalkan kekayaan pemegang saham. Faktor-faktor yang dapat mempengaruhi nilai perusahaan adalah kebijakan keuangan yang terdiri dari keputusan investasi, leverage keuangan, dan kebijakan dividen. Selain kebijakan keuangan, terdapat faktor lain yang dapat mempengaruhi nilai perusahaan yaitu kepemilikan manajerial, profitabilitas, dan ukuran perusahaan. Oleh karena itu, penelitian ini bertujuan untuk menguji pengaruh kebijakan keuangan, kepemilikan manajerial, profitabilitas, dan ukuran perusahaan terhadap nilai perusahaan pada perusahaan sub sektor otomotif dan komponen yang terdaftar di Bursa Efek Indonesia tahun 2014-2018. Teknik analisis data yang digunakan dalam penelitian ini adalah analisis regresi linier berganda dan pengujian hipotesis menggunakan uji $\mathrm{t}$, uji $\mathrm{F}$, dan koefisien determinasi. Hasil penelitian menunjukkan bahwa secara parsial keputusan investasi, kebijakan dividen, kepemilikan manajerial, dan ukuran perusahaan tidak berpengaruh terhadap nilai perusahaan, sedangkan financial leverage dan profitabilitas berpengaruh terhadap nilai perusahaan. Secara simultan keputusan investasi, financial leverage, kebijakan dividen, kepemilikan manajerial, profitabilitas, dan ukuran perusahaan berpengaruh terhadap nilai perusahaan.
\end{abstract}

Kata kunci -Kebijakan Keuangan; Kepemilikan Manajerial; Profitabilitas; Ukuran perusahaan; Nilai Perusahaan.

\section{INTRODUCTION}

According to Statistics Indonesia (2018), the economic growth of Indonesia in 2017 reached 5.07 percent and the economic growth of Indonesia in 2018 grew into 5.17 percent, higher than the achievement in 2017. The number, according to Statistics Indonesia was the highest economic growth since the past 2014. Automotive and component sub-sector was one of the important sectors that had great contribution to the economy of Indonesia. It could be seen that the contribution to Indonesian GDP in 2016 reached 10.47 percent and in 2017 in reached 
10.17 percent (kemenperin.go.id, 2019). According to IDX Statistics in various industrial sectors, automotive and component sub-sector had the highest profit among other sub-sectors from 2014 to 2018. The availability of information regarding profit of company financial statement would make investors understand about the company's performance. It was certainly done by investors to obtain investment decision alternative well to secure the sustainability of their investment value enhancement.

From 2014 to 2018, Indonesia was the greatest car market in ASEAN. The greatest sales in 2014, 2015, 2016, 2017, and 2018 occurred in Indonesia. The greatest sales occurred in 2014 reaching 1,208,019 units, in 2015 in number of 1,013,291 units, in 2016 in number of 1,061,735 units, in 2017 in number of 1,100,000 units, and in 2018 in number of 1,200,000 units (katadata.co.id, 2018). It became an attraction for Indonesia as an investment destination of some international automotive companies.

In general, each company aims to optimize their profit and their company value for the investors (Wijaya, 2017). Company value also refers to market value because if the share price of a company increases, the company value can secure the shareholders' welfare optimally (Hermawan \& Mafulah, 2014). In the study, the researcher implemented Tobin's Q calculation to measure the company value. Tobin's Q can represent company performance in long term and can provide value presentation given to investors on tangible and intangible assets based on income prediction and cost flow (Shan, 2011).

There are direct and indirect factors that can affect company value. The direct factors are the factors that can directly affect company value while the indirect factors are the factors that can affect company value by passing dividend policy first. Theoretically, some factors of company characteristics can affect company value, both directly and indirectly. The factors are investment decision, financial leverage, managerial ownership, profitability, and company size. However, the study investigated the effect of the factors on company value directly (Rizkia et al., 2013).

According to Afzal and Rohman (2012), company value can be said good if the company can combine all or some of the functions available in financial management. It can be observed from a fact that if the company determines a financial decision, it will be able to give effect on other financial decisions, so it will also have effect on company value. According to Wijaya (2017:2), one of decisions that can affect company value is dividend policy. Dividend policy is a policy owned by a company aimed to determine current annual income of the company to be given to investors or whether the income will be retained as investment reserve for the following year.

Dividend payment is an information that the company is in great condition, even investors view dividend distribution as a sign that the company performance is good and it has surplus fund (Manurung, 2012:112). It can be observed from share dividend of a company in automotive and component sub-sector, namely PT Astra International Tbk:

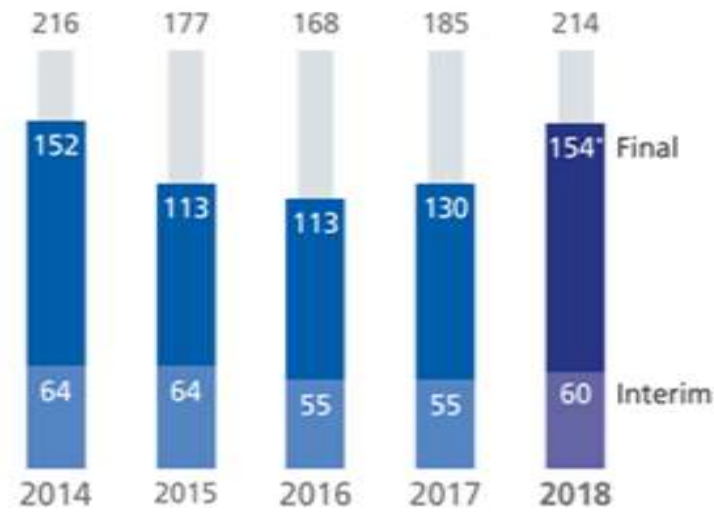

Figure 1. Chart of Share Dividend of Astra Year 2014-2018 (Bareksa.com, 2019)

PT Astra International Tbk (ASII) distributed cash dividend in accounting year 2018 in amount of IDR 214 per share or in total amount of IDR 8.67 trillion. The dividend in accordance with the resolution of Annual General Meeting of Shareholders (AGMS) of PT Astra International Tbk included interim dividend IDR 60 per share paid on 31 October 2018. The dividend of Astra in accounting year 2018 turned out to be the highest since 2014. From 
the chart above, Astra kept experiencing dividend decrease from 2014, namely IDR 177 per share in 2015 and IDR 168 per share in 2016. While Astra started to increase its dividend in 2017 into IDR 185 along with its increasingly better financial statement (Bareksa.com, 2019). Therefore, PT Astra International Tbk could give positive signal to investors to invest in the company in the following years to enhance company value in the eyes of investors (Astra.co.id, 2019). In addition to dividend policy, managerial ownership also becomes one of the factors that can affect company value (Tambalean et al., 2018). According to Swandari (2012), managerial ownership is shareholding of management of a company that can be observed from the share proportion held by the management. While managerial ownership is expected to fulfill each interest of manager and shareholder, and also a form of supervision on the policies taken by company management.

The second factor is financial leverage. Financial leverage is a company resolution taken to find fund, and reflected on the right side of financial position report that gives information about how much the proportion of liability and equity of the company is (Wijaya, 2017:1). The study conducted by Nurchanifia (2012) states that financial leverage has unidirectional effect on company value through decrease, vice versa if financial leverage decreases, it will cause increase of company value. The unidirectional effect is caused by the fact that if the debt percentage of a company is quite high, it can cause share price that is the illustration of company value decreases. For example, in automotive and component sub-sector companies, it can be observed from Table 1.

Table 1. Average Total Liability and Average Value of Tobin's Q in Automotive and Component SubSectors

\begin{tabular}{|c|c|c|c|c|c|}
\hline Description & 2014 & 2015 & 2016 & 2017 & 2018 \\
\hline $\begin{array}{l}\text { Average } \\
\text { Liability }\end{array}$ & IDR 13,913 & IDR 12,397 & IDR 12,733 & IDR 14,307 & IDR 18,888 \\
\hline Average Tobin's $Q$ & 1.4383 & 1.3242 & 1.2163 & 1.2169 & 1.2047 \\
\hline
\end{tabular}

Description: The data of total liability is expressed in billion rupiahs

Source: Financial Statement of Automotive and Component Sub-Sector Companies,

Data Processed by the Writer (2019)

Based on some phenomena and theories above, the study aimed to test the effect on financial policy, managerial ownership, profitability, and company size of company value in automotive and component sub-sector companies registered in Indonesia Stock Exchange period 2014-2018.

\section{LITERATURE REVIEW}

\section{A. Company Value}

The main goal of a company is to optimize company value by securing the investors' welfare. Optimizing company value can be interpreted as a way of the company to optimize company value when it enters the market or goes public (Fahmi, 2011). Company value in the study was proxied using Tobin's Q ratio. Tobin's Q is the market value of a company's asset with its replacement cost (Margaretha, 2014). While the formula of Tobin's Q is:

$$
\text { Tobin's Q }=\frac{\text { Total Market Value }+ \text { Total Book Value of Liabilities }}{\text { Total Book Value Of Assets }}
$$

\section{B. Investment Decision}

Investment decision is a policy of usage of fund sourced from outside of the company from various kinds of assets (Yuliariskha, 2015). Investment decision in the study was proxied by Capital Expenditure to Book Value of Assets (CAP/BVA). CAP/BVA is used to investigate how much the growth of a company's share capital is (Dahlan in Suwandi, 2016). While the formula of CAP/BVA is:

$$
\text { CAP/BVA }=\frac{\text { Total Fixed Asset }(\mathrm{t})-\text { Total Fixed Asset }(\mathrm{t}-1)}{\text { Total Asset }(\mathrm{t})}
$$

The result of the study conducted by Mardiyati et al. (2015) states that investment decision proxied by Capital Expenditure to Book Value of Asset (CAP/BVA) gives positive and significant effect on company value. 
Similarly, the result of the study by Rizkia et al. (2013) states that investment decision gives positive and significant effect on company value, it indicates that the quality of investment policy in capital issuance decision making can determine share price reaction and enhance company value. The hypothesis built is:

H1: Investment decision has effect on company value.

\section{Financial Leverage}

Financial leverage is the situation where a company uses a fund source that has fixed burden with purpose to enhance income per share (Kamaludin, 2012). Financial leverage in the study was proxied by Debt to Asset Ratio (DAR). Debt to Asset Ratio is the ratio to observe the comparison between total debt and total asset (Maulita and Tania, 2018). While the formula of DAR is:

$$
\mathrm{DAR}=\frac{\text { Total Debt }}{\text { Total Asset }}
$$

The result of the study conducted by Ogolmagai (2013) states that financial leverage proxied by Debt to Asset Ratio (DAR) had no effect on company value. While the result of the study by Rizkia et al. (2013) states that financial leverage had positive effect on company value, it indicates that financial leverage can be used to enhance company value. The hypothesis built is:

H2: Financial leverage has effect on company value.

\section{Dividend Policy}

Dividend policy is a crucial policy for a company. The company has to be able to manage the profit earned, either by distributing the profit in form of dividend or by retaining the profit, it is because the company has to survive in the middle of tight competition. In the study, dividend policy was measured using Dividend Payout Ratio (DPR). DPR is the proportion between dividend per share distributed and the profit per share (Nidar, 2016). While the formula of DPR is:

$$
\mathrm{DPR}=\frac{\text { Dividend } \text { per share }}{\text { Earning per share }}
$$

Dividend payment is a strategy used so that the company experiences enhancement. Dividend payment in cash to the shareholders is considered able to enhance company value (Manurung, 2012:107).

The study conducted by Widyanti (2014) states that dividend payment has effect on company value. While the result of the study conducted by Pamungkas and Puspaningsih (2013) states that dividend payment has no effect on company value, it can be interpreted that dividend distribution cannot attract investors' attention fully to purchase shares. So, the hypothesis built is:

H3: Dividend payment has effect on company value.

\section{E. Managerial Ownership}

Managerial ownership is the comparison of shareholders belonging to the management of the company involved in decision making in the company. Great managerial ownership in a company will be more effective to supervise the activities of the company (Sartono, 2010). In the study, managerial ownership was proxied by Managerial Ownership (MOWN). MOWN is a ratio showing the proportion between total shares held by the management of the company and the total circulating shares (Rizkia et al., 2013). While the formula of MOWN is:

$$
\text { MOWN }=\frac{\text { Total Managerial Shares }}{\text { Total Circulating Shares }}
$$

According to Budianto and Payamta (2014), optimal composition of ownership structure has effect on company performance. While the study conducted by Tambalean et al. (2018) states that managerial ownership has no significant effect on company value. However, the result of the study by Rizkia et al. (2013) states that managerial ownership has positive effect on company value. So, the hypothesis built is:

H4: Managerial ownership has effect on company value. 


\section{F. $\quad$ Profitability}

Profitability is the ability of a company to earn profit in long term. The ratio is important for investors, because to make investment, investors always calculate the profit they will receive in form of dividend (Sartono, 2010). In the study, investment decision was measured using Return on Asset (ROA). ROA is the return on the company's owner's asset. While the formula of ROA is:

$$
\mathrm{ROA}=\frac{\text { Net Profit }}{\text { Total Asset }}
$$

According to Mardiyati et al. (2015), profitability has effect on company value. It is because high profitability will attract future investors' attention to invest in the company.

The study conducted by Widyanti (2014) states that profitability measured by Return on Equity on company value, it is because the higher profitability ratio, the more appropriately the company calculates the profit to be received by ordinary shareholders. It can give good response to investors to take investment decision. Similarly, that result of the study by Rizkia et al. (2013) states that profitability measured by Return on Asset has positive effect on company value. So, the hypothesis built was:

H5: Profitability has effect on company value.

\section{G. Company Size}

Company size can determine how big or how small a company can be measured by its total assets, volume of sales, average total sales, and average total assets (Rizkia et al., (2013). In the study, company size was based on total assets, so the formula used to measure company size is as the following:

$$
\text { Company Size = Ln Total Asset }
$$

The study conducted by Pamungkas and Puspaningsih (2013) states that company size has no effect on company value, it can be interpreted that big company size is not always able to enhance company value. However, the result of the study by Rizkia et al. (2013) states that company size has positive effect on company value. So, the hypothesis built is:

H6: Company size has effect on company value.

While the hypothesis built to observe the effect of all variables on company value is:

H7: Dividend policy, investment decision, financial leverage, managerial ownership, profitability, and company size simultaneously have effect on company value.

\section{RESEARCH MethodS}

Based on the method, the study was classified as quantitative research. The sampling technique used was purposive sampling technique. The data used in the study were secondary data. The data analysis implemented in the study was multiple linear regression. The hypothesis testing in the study applied t test, $\mathrm{F}$ test, and coefficient of determination. The research population is Automotive and component sub-sector companies registered in IDX year 2014-2018. The sampling technique used was purposive sampling, and 5 companies were selected as the samples.

\section{RESUlT AND DISCUSSION}

A. Statistic Descriptive Analysis 
The following is example of each operational variable based on data of PT Astra International Tbk 2014.

$$
\begin{gathered}
\text { Tobin's }=\frac{(40.483 .553 .140 \times 7.425)+115.705 .000 .000 .000}{236.029 .000 .000 .000}=\frac{416,295,382,064.500}{236.029 .000 .000 .000}=1,7637 \\
\frac{C A P}{B V A}=\frac{41.250-37.862}{236.029}=0,0144 \\
D A R=\frac{115.705}{236.029}=0,4902 \\
D P R=\frac{152}{22.125 .000 .000 .000 / 40.483 .553 .140} \\
M O W N=\frac{11.615 .000}{40.483 .553 .140}=0,0003 \\
R O A=\frac{22.125}{236.029}=0,0937 \\
\text { Company Size }=\operatorname{Ln}(\operatorname{Rp} .236 .029 .000 .000 .000)=33,0950
\end{gathered}
$$

Tabel 2. Statistic Descriptive of Automotive and Component Sub-Sector Companies

\begin{tabular}{|l|r|r|r|r|r|}
\hline \multicolumn{7}{|c|}{ Descriptive Statistics } \\
\hline & $\mathrm{N}$ & Minimum & \multicolumn{1}{c|}{ Maximum } & \multicolumn{1}{c|}{ Mean } & Std. Deviation \\
\hline Investment Decision (X1) & 25 &,- 0503 &, 1801 &, 020800 &, 0516169 \\
\hline Financial Leverage (X2) & 25 &, 1161 &, 7019 &, 391896 &, 1834301 \\
\hline Dividend Policy (X3) & 25 &, 0000 &, 5775 &, 178480 &, 1600571 \\
\hline Managerial Ownership (X4) & 25 &, 0003 &, 2887 &, 076604 &, 1123848 \\
\hline Profitability (X5) & 25 &,- 0179 &, 2409 &, 081000 &, 0791065 \\
\hline Company Size (X6) & 25 & 28,1903 & 33,4737 & 29,954428 & 1,8457603 \\
\hline Tobin's Q (Y1) & 25 &, 3385 & 4,2535 & 1,465080 & 1,0633109 \\
\hline Valid N (listwise) & 25 & & & & \\
\hline
\end{tabular}

Source: Processed Data (2019)

Table 2 explains that the Tobin's Q variable has the lowest value of 0.3385 and the highest value of 4.2535 with an average of 1.4651 and a standard deviation of 1.0633 . The investment decision variable has the lowest value of -0.0503 and the highest value of 0.1801 with an average value of 0.0208 and a standard deviation of 0.0516 . The financial leverage variable has the lowest value of 0.1161 and the highest value of 0.7019 with an average value of 0.3919 and a standard deviation of 0.1834 . The dividend policy variable has the lowest value of 0 and the highest value of 0.5775 with an average of 0.1785 and a standard deviation of 0.1601 . The managerial ownership variable has the lowest value of 0.0003 and the highest value of 0.2887 with an average of 0.0766 and a standard deviation of 0.1124 . The profitability variable has the lowest value of -0.0179 and the highest value of 0.2409 with an average of 0.0810 and a standard deviation of 0.0791 . The firm size variable has the lowest value of 28.1903 and the highest value of 33.4737 with an average of 29.9544 and a standard deviation of 1.8458 .

B. Classical Assumption Test 


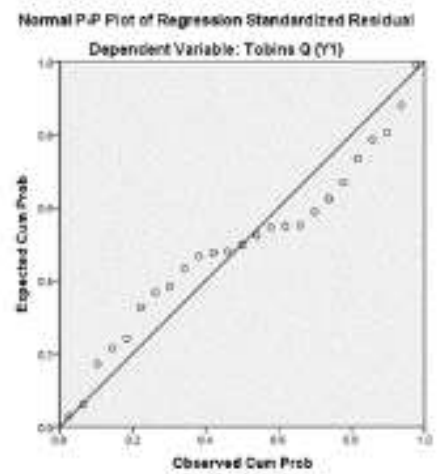

Figure 2. Scatterplot of Result of Normality Test (Processed Data, 2019)

Based on the result of normality test in Figure 2 above, it is found that the graphic display appears to meet the assumption of normality test. It is because the data only spread around the diagonal line and following the direction of the diagonal line. Therefore, it shows that the data in the study were normally distributed.

Table 3. Result of Multicollinearity Test

\begin{tabular}{|c|c|c|c|c|c|c|c|}
\hline \multicolumn{8}{|c|}{ Coefficients $^{\mathbf{a}}$} \\
\hline & \multicolumn{2}{|c|}{$\begin{array}{l}\text { Unstandardized } \\
\text { Coefficients }\end{array}$} & \multirow{2}{*}{$\begin{array}{c}\begin{array}{c}\text { Standardized } \\
\text { Coefficients }\end{array} \\
\text { Beta }\end{array}$} & & & \multicolumn{2}{|c|}{ Collinearity Statistics } \\
\hline & B & Std. Error & & & & Tolerance & VIF \\
\hline (Constant) & -.597 & 1.154 & & -.517 & 611 & & \\
\hline Investment Decision (X1) & .618 & 1.048 & .030 & .589 & .563 & .902 & 1.109 \\
\hline Financial Leverage (X2) & 1.307 & .429 & .226 & 3.051 & .007 & .427 & 2.343 \\
\hline \begin{tabular}{|l} 
Dividend Policy (X3) \\
(X)
\end{tabular} & -.386 & .425 & -.058 & -.907 & .376 & .570 & 1.754 \\
\hline Managerial Ownership (X4) & -.332 & .587 & -.035 & -.565 & .579 & .606 & 1.651 \\
\hline Profitability (X5) & 14.018 & .700 & 1.043 & 20.015 & .000 & .859 & 1.164 \\
\hline Company Size (X6) & .017 & .042 & .029 & .395 & .698 & .441 & 2.268 \\
\hline
\end{tabular}

Source: Processed Data (2019)

From the result of multicollinearity test in Table 2, it can be concluded that multicollinearity did not occur among the six variables or they were free from multicollinearity because the tolerance value of the six variables above was 0.10 and the VIF value of the six variables was lower than 10.00 .

Table 4. Result of Autocorrelation Test

\begin{tabular}{|l|r|}
\hline \multicolumn{2}{|c|}{ Runs Test } \\
\hline & $\begin{array}{c}\text { Unstandardized } \\
\text { Residual }\end{array}$ \\
\hline Test Value $^{\mathrm{a}}$ & -.00792 \\
\hline Cases < Test Value & 12 \\
\hline Cases >= Test Value & 13 \\
\hline Total Cases & 25 \\
\hline Number of Runs & 13 \\
\hline Z & .000 \\
\hline Asymp. Sig. (2-tailed) & 1.000 \\
\hline
\end{tabular}


From the result of autocorrelation test in Table 3 above, it is found that the value of processed data significance was higher than 0.05 , namely 1.000. It indicates that the data in the study were free from autocorrelation or autocorrelation did not occur.

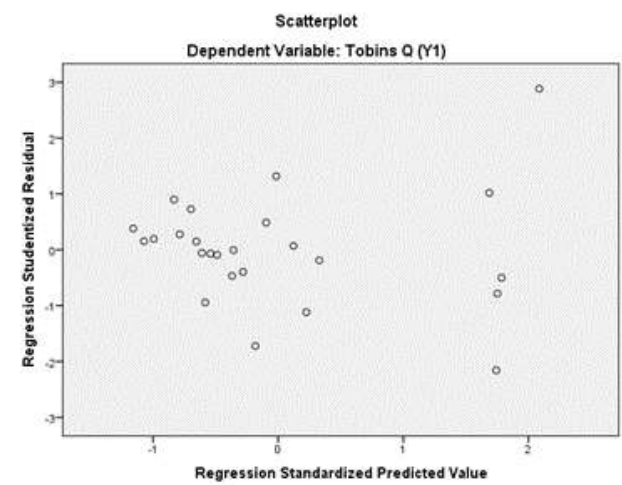

Figure 2. Result of Heteroskedasticity Test (Source: Processed Data, 2019)

Based on the result of heteroskedasticity test in Table 2 above, it is found that there is no pattern in the chart, such as wavy, converging in the middle, narrowing then widening, or otherwise widening then narrowing. Therefore, it indicates that the data in the study were free from heteroskedasticity or heteroskedasticity did not occur.

\section{Multiple Linear Regression}

From the result of multiple linear regression in the table above, the equation of multiple linear regression of the study is found as the following:

$$
Y=-0.597+0.618 X_{1}+1.307 X_{2}-0.386 X_{3}-0.332 X_{4}+14.018 X_{5}+0.017 X_{6}
$$

Where:

$$
\begin{array}{ll}
Y & =\text { Dependent variable } \\
a & =\text { Constant } \\
\beta_{1} \beta_{2} \beta_{3} \beta_{4} \beta_{5} \beta_{6} & =\text { Regression coefficient } \\
X_{1} X_{2} X_{3} X_{4} X_{5} X_{6}= & \text { Independent variable } \\
e & =\text { Error }
\end{array}
$$

\section{Hypothesis Testing}

a. Partial Test (t Test)

The result of partial test can be observed from Table 2, the investment decision variable proxied by Capital Expenditure to Book Value of Asset (CAP/BVA) had significant value of $0.563>0.05$, so $\mathrm{H}_{0}$ was accepted and $\mathrm{H}_{\mathrm{a}}$ was rejected, it illustrated that investment decision partially had no effect on company value.

Based on Table 2, the financial leverage variable proxied by Debt to Asset Ratio (DAR) had significant value of $0.007<0.05$, so $\mathrm{H}_{0}$ was rejected and $\mathrm{H}_{\mathrm{a}}$ was accepted, it means that financial leverage partially had effect on company value. 
Based on Table 2, the dividend policy variable proxied by Dividend per Payout Ratio (PDR) had significant value of $0.376>0.05$, so $\mathrm{H}_{0}$ was accepted and $\mathrm{H}_{\mathrm{a}}$ was rejected, it means that dividend policy partially had no effect on company value.

Based on Table 2, the managerial ownership variable proxied by Managerial Ownership (MOWN) had significant value of $0.597>0.05$, so $\mathrm{H}_{0}$ was accepted and $\mathrm{H}_{\mathrm{a}}$ was rejected, it means that managerial ownership partially had no effect on company value.

Based on Table 2, the profitability variable proxied by Return on Assets (ROA) had significant value of $0.000<0.05$, so $\mathrm{H}_{0}$ was rejected and $\mathrm{H}_{\mathrm{a}}$ was accepted, it means that profitability partially had effect on company value.

Based on Table 2, the company size variable proxied by Ln Total Asset had significant value of $0.698>$ 0.05, so $\mathrm{H}_{0}$ was accepted and $\mathrm{H}_{\mathrm{a}}$ was rejected, it means that company size partially had no effect on company value.

\section{b. Simultaneous Test (F Test)}

Based on the result of simultaneous test in Table 4, it is found that the significant value in the ANOVA table was 0.000 . It means that the significant value was $0.000<0.05$, so $\mathrm{H}_{0}$ was rejected and $\mathrm{H}_{\mathrm{a}}$ was accepted, it means that there was simultaneous effect between the investment decision, financial leverage, dividend policy, managerial ownership, profitability, and company size variable on the company value variable. It means that investment decision, financial leverage, dividend policy, managerial ownership, profitability, and company size simultaneously had effect on company value.

Table 5. Result of Simultaneous Hypothesis Testing (F Test)

ANOVA $^{\mathrm{a}}$

\begin{tabular}{|l|l|r|r|r|c|c|}
\hline \multicolumn{2}{|l|}{ Model } & $\begin{array}{r}\text { Sum of } \\
\text { Squares }\end{array}$ & df & $\begin{array}{c}\text { Mean } \\
\text { Square }\end{array}$ & F & Sig. \\
\hline \multirow{2}{*}{ Regression } & 25.996 & 6 & 4.333 & 68.443 & $.000^{\mathrm{b}}$ \\
\cline { 2 - 7 } & Residual & 1.139 & 18 & .063 & & \\
\cline { 2 - 7 } & Total & 27.135 & 24 & & & \\
\hline
\end{tabular}

Source:

Processed Data, 2019

Based on the result of simultaneous testing in Table 4, it is found that the significant value in the ANOVA table was 0.000 . It means the significant value $0.000<0.05$, so $\mathrm{H}_{0}$ was rejected and $\mathrm{H}_{\mathrm{a}}$ was accepted, it means that there was simultaneous effect between the investment decision, financial leverage, dividend policy, managerial ownership, profitability, and company size variable on the company value variable. It means that investment decision, financial leverage, dividend policy, managerial ownership, profitability, and company size simultaneously had effect on company value.

\section{E. Discussion}

Investment decision had no effect on company value in the study, it is in line with Dewi and Wirasedana (2018). It can be caused by the absence of certainty in the future. The uncertainty can include technological changes, socioeconomic conditions, and government's policies. In making investment decision, managers have to anticipate those factors, if managers do not anticipate nor consider those factors, it can cause inappropriateness of investment decisions taken, so investment decision cannot be used as a tool to enhance company value. In addition, investment decision in the study was only observed based on the changes of fixed assets of the companies. Therefore, it could not illustrate the investment decisions taken by the companies entirely. If the assets of current year decrease, the assets of next year will not necessarily decrease, so it cannot attract investors' attention. The result of the study is different from the result of the study by Pamungkas and Puspaningsih (2013), Mardiyati et al. (2015), and Rizkia et al. (2013). The difference of samples and research period could cause the difference between current condition and the previous studies so it could also become a causing factor that investment decision had no effect on company value.

Financial leverage having effect on company value is in accordance with the study by Dewi and Wirasedana (2018) and Rizkia et al. (2013). According to Dewi and Wirasedana, financial leverage has effect on company 
value, it agrees with the signal theory that states that a company that increases the amount of debt is considered sure about its future prospect. According to external parties, by increasing the amount of debt, the company is able to pay its obligations in the future or there is low business risk for shareholders, which is then responded positively by the market. In the study, financial leverage had effect on company value, it was brought by PT Astra International Tbk, PT Indo Kordsa Tbk, PT Indospring, and PT Selamat Sempurna. The four companies in the study had financial leverage of lower than $50 \%$ from 2014 to 2018. It can be interpreted that the four companies did not use much funding from debt, so the financial performance of the four companies could be said to be good. It could attract investors because less than $50 \%$ of the assets owned by the companies were funded by debt. The result of the study is not in line with the result of the study by Ogolmagai (2013) stating that financial leverage has no effect on company value.

The result of the study agrees with the result of the study by Anita and Yulianto (2016) stating that dividend policy has no effect on company value, but it does not agree with the result of the study by Mardiyati et al. (2015) stating that dividend policy has effect on company value. The result of the study conforms to the theory of Dividend Irrelevance proposed by Franco Modigliani and Merton Miller. The theory explains that dividend policy has no effect on company value. Modigliani and Miller state that company value can be affected by the performance of a company in the efforts to earn income and business risk, but the policy in distributing income in form of dividend or retained profit has no effect on company value (Sudana, 2011:168). It is also in accordance with the idea of Anita and Yulianto (2016) stating that dividend policy has no effect on company value because shareholders have a purpose to earn profit in short term, namely by earning profit through capital gain. Some shareholders have changed their mind from earning profit through dividend into earning profit through capital gain. It is because earning profit through capital gain requires shorter time than waiting for distribution of dividend from the company which requires quite long time.

The result of the study agrees with the result of the study by Tambalean et al. (2018) and the result of the study by Sukirni (2012) stating that managerial ownership has no effect on company value, but it does not agree with the result of the study by Rizkia et al. (2013) stating that managerial ownership has effect on company value. According to Sukirni (2012), managerial ownership having no effect on company value was caused by the small number of the management of the company who held shares with high percentage in the companies. The low percentage of shareholding by the management could cause the management of the company to prioritize their personal interest rather than the company's interests.

The result of the study agrees with the result of the study by Rizkia et al. (2013) and the result of the study by Mardiyati et al. (2015) stating that profitability has effect on company value, but it does not agree with the result of the study by Nugroho and Abdani (2017) stating that profitability has no effect on company value. Profitability having effect on company value is because investors have an assumption that the company can manage its equity efficiently so it can earn net profit, which gives positive impact on company value. The higher profit earned by the company, the higher company value. It is because a company with high profit can attract investors' attention, because it can lead investors to participate in increasing the demands on the company's shares (Mardiyati et al., 2015). The result of the study indicates that profitability had effect on company value, it was because only one company namely PT Gajah Tunggal Tbk in 2015 and 2018 had negative net profit or suffered from loss. While PT Astra International Tbk, PT Indo Kordsa Tbk, PT Indospring Tbk, and PT Selamat Sempurna Tbk from 2014 to 2018 always earned positive net profit or gained profit. Therefore, profitability in automotive and component sub-sector companies could attract investors' attention to invest.

The result of the study agrees with the result of the study by Rahmawati et al. (2015) and the result of the study by Herawati (2017) stating that company size has no effect on company value, but it does not agree with the result of the study by Mardiyati et al. (2015) stating that company size has effect on company value. According to Herawati, company size can be measured from its total assets. A company that has high total assets cannot guarantee to pay dividend to investors. Companies choose to maintain their profit rather than to distribute it as dividend to investors that can affect share price and company value. Therefore, it can be said that companies with high total assets cannot guarantee investors to invest in the companies. The idea of Herawati (2017) conforms to the study, which can be observed from the value of Ln Total Assets of PT Gajah Tunggal Tbk from 2014 to 2018 that had the second greatest Ln Total Assets after PT Astra International Tbk. However, in 2015, 2016, and 2018 PT Gajah Tunggal Tbk did not distribute dividend to investors. It can be said that companies with great total asset do not necessarily distribute it as dividend, so it causes company size not able to convince investors to invest. 


\section{CONCLUSSION}

1. Investment decision has no effect on company value in automotive and component sub-sector companies registered in Indonesia Stock Exchange period 2014-2018.

2. Financial leverage has significant effect on company value in automotive and component sub-sector companies registered in Indonesia Stock Exchange period 2014-2018.

3. Dividend policy has no effect on company value in automotive and component sub-sector companies registered in Indonesia Stock Exchange period 2014-2018.

4. Managerial ownership has no effect on company value in automotive and component sub-sector companies registered in Indonesia Stock Exchange period 2014-2018.

5. Profitability has significant effect on company value in automotive and component sub-sector companies registered in Indonesia Stock Exchange period 2014-2018.

6. Company size has no effect on company value in automotive and component sub-sector companies registered in Indonesia Stock Exchange period 2014-2018.

7. Investment decision, financial leverage, dividend policy, managerial ownership, profitability, and company size simultaneously have effect on company value in automotive and component sub-sector companies registered in Indonesia Stock Exchange period 2014-2018.

8. From the results of this research, profitability and financial leverage have effects on firm value, therefore companies should continue to maintain the level of profit in order to attract investors' trust to keep investing in the company. Beside profitability, companies must also remain careful in using debt to carry out operational activities, because debt can be a risk for the company if the company is unable to fulfill these obligations.

\section{REFERENCES}

Afzal, Arie dan Rohman, A. (2012). Pengaruh Kebijakan Investasi, Kebijakan pendanaan, dan Kebijakan Dividen terhadap Nilai Perusahaan. Diponegoro Journal of Accounting, 1(2), 1-9.

Almawadi, I. (2019). Selamat! Astra Bagi Dividen Rp214 per Saham, Terbesar Sejak 2014. [online]. https://www.bareksa.com/id/text/2019/04/25/selamat-astra-bagi-dividen-rp214-per-saham-terbesar-sejaktahun-2014/22135/news [7 September 2019].

Anita, Aprilia., dan Yulianto, Arief. (2016). Pengaruh Kepemilikan Manajerial dan Kebijakan Dividen Terhadap Nilai Perusahaan. Management Analysis Journal, 5(1), 17-24.

Budianto, Wahyu., dan Payamta. (2014). Pengaruh Kepemilikan Manajerial Terhadap Nilai Perusahaan Dengan Kebijakan Dividen Sebagai Variabel Moderasi. Jurnal Akuntansi dan Pendidikan, 13(1), 1-13.

Dahlan, Fitriani., dan Suwandi, Memen. (2016). Pengaruh Keputusan Investasi Terhadap Nilai Perusahaan Jasa Perbankan Yang Terdaftar Di Bursa Efek Indonesia. Akuntansi Peradaban, 2(1), 64-88.

Fahmi, Irham. (2011). Analisis Kinerja Keuangan Panduan bagi Akademisi, Manajer, dan Investor untuk Menilai dan Menganalisis Bisnis dari Aspek Keuangan. Bandung: CV Alfabeta.

Hermawan, Sigit., dan Maf'ulah, Afiyah Nurul. (2014). Pengaruh Kinerja Keuangan Terhadap Nilai Perusahaan Dengan Pengungkapan Corporate Social Responsibility Sebagai Variabel Pemoderasi. Jurnal Dinamika Akuntansi, 6(2), 103 - 118.

Herawati, Lidya Nafitri Ayu. (2017). Pengaruh Ukuran Perusahaan, Leverage, Pertumbuhan Penjualan Dan Profitabilitas Terhadap Nilai Perusahaan Pada Perusahaan Yang Terdaftar Dalam Indeks LQ45. STIE Perbanas Surabaya, 1(2), 1-16.

Kamaludin, Rini Indriani. (2012). Manajemen Keuangan. Bandung: Mandar Maju.

Manurung, Adler Haymans. (2012). Teori Keuangan Perusahaan. Jakarta: PT Adler Manurung Press.

Mardiyati, Umi., Ahmad, Gatot Nizar., dan Abrar, Muhammad. (2015). Pengaruh Keputusan Investasi, Keputusan Pendanaan, Ukuran Perusahaan Dan Profitabilitas Terhadap Nilai Perusahaan Pada Sektor Manufaktur Barang Konsumsi Yang Terdaftar Di Bursa Efek Indonesia Periode 2010-2013. Jurnal Riset Manajemen Sains Indonesia (JRMSI), 6(1), 417-439.

Margaretha, Farah. (2014). Dasar - Dasar Manajemen Keuangan. Jakarta: Dian Rakyat.

Maulita, Dian., dan Tania, Inta. (2018). Pengaruh Debt To Equity Ratio (DER), Debt To Asset Ratio (DAR), Dan Long Term Debt To Equity Ratio (LDER) Terhadap Profitabilitas (Studi Pada Perusahaan Manufaktur Sub Sektor Makanan Dan Minuman Yang Terdaftar Di Bei Periode 2011-2016). Jurnal Akuntansi, 5(2), 132137.

Nidar, Sulaeman Rahman. (2016) Manajemen Keuangan Perusahaan Modern. Bandung: Pustaka Reka Cipta. 
Nugroho, Wawan Cahyo., dan Abdani, Fadil. (2017). Pengaruh Profitabilitas, Dividend Policy, Leverage, Dan Keputusan Investasi Terhadap Nilai Perusahaan Konstruksi Di Bursa Efek Indonesia. El-Muhasaba, 8(1), 104-122.

NN. (2018). Industri Otomotif Berkontribusi 10,16 Persen Kepada Perekonomian Nasional. [online]. https://kemenperin.go.id/artikel/19008/Industri-Otomotif-Berkontribusi-10,16-Persen-KepadaPerekonomian-Nasional [4 September 2019].

NN. (2018). Indonesia Tetap Memimpin Penjualan Mobil di ASEAN. [online]. https://databoks.katadata.co.id/datapublish/2018/02/12/indonesia-tetap-memimpin-penjualan-mobil-diasean [5 September 2019].

Nurchanifia, Siti. (2012). Analisis Pengaruh Finacial Leverage Terhadap Nilai Perusahaan pada Industri Makanan dan Minuman yang terdaftar di bursa Efek Indonesia. Jurnal Ekonomi dan Bisnis Sekolah Ilmu Ekonomi Perbanas. Surabaya, 5(2), 1-15.

Ogolmagai, Natalia. (2013). Leverage Pengaruhnya Terhadap Nilai Perusahaan Pada Industri Manufaktur Yang Go Public Di Indonesia. Jurnal EMBA, 1(3), 81-89.

Pamungkas, Hesti Setyorini., dan Puspaningsih, Abriyani. (2013). Pengaruh Keputusan Investasi, Keputusan Pendanaan, Kebijakan Dividen Dan Ukuran Perusahaan Terhadap Nilai Perusahaan. Jurnal JAAI, 17(2), 156-165.

Rahmawati, Amalia Dewi., Topowijono., dan Sulasmiyati, Sri. (2015). Pengaruh Ukuran Perusahaan, Profitabilitas, Struktur Modal, Dan Keputusan Investasi Terhadap Nilai Perusahaan (Studi pada Perusahaan Sektor Properti, Real Estate, dan Building Construction yang Terdaftar di Bursa Efek Indonesia (BEI) Periode 2010-2013). Jurnal Administrasi Bisnis, 23(2), 1-7.

Rizkia, Dwita Ayu., Aisjah, Siti., dan Sumiati. (2013). Effect of Managerial Ownership, Financial Leverage, Profitability, Firm Size, and Investment Opportunity on Dividend Policy and Firm Value. Journal of Finance and Accounting. 4(11), 120-130.

Sartono. R. Agus. (2010). Manajemen Keuangan Teori dan Aplikasi. Yogyakarta: BPFE-Yogyakarta.

Shan, Yuan George., dan McIver, Ron P. (2011). Corporate Governance Mechanisms and Financial Performance in China: Panel Data Evidence on Listed non Financial Companies. Asia Pacific Business Review, 17(3), 301-324.

Sudana, I Made. (2011). Manajemen Keuangan Perusahaan Teori dan Praktek. Surabaya: Erlangga.

Sukirni, Dwi. (2012). Kepemilikan Manajerial, Kepemilikan Institusional, Kebijakan Dividen, dan Kebijakan Hutang Analisis Terhadap Nilai Perusahaan. Accounting Analysis Journal, 1(2), 1-12.

Swandari, Fifi. (2012). Pengaruh Struktur Kepemilikan Terhadap Tingkat Risiko dan Implikasinya Terhadap Kesulitan Keuangan Bank Umum di Indonesia. Jurnal Ekobi, 9(1), 38-41.

Tambalean, Friko Allan Kevin., Monossoh, Hendrik., dan Runtu, Treesje. (2018). Pengaruh Kepemilikan Manajerial Dan Kepemilikan Institusional Terhadap Nilai Perusahaan Pada Perusahaan Sektor Industri Barang Konsumsi Di BEI. Jurnal Riset Akuntansi Going Concern, 13(4), 465-473.

Widyanti, Ratna Ayu. (2014). Pengaruh Profitabilitas, Dividend Payout Ratio, Dan Corporate Social Responsibility Terhadap Nilai Perusahaan Sektor Manufaktur. Jurnal Ilmu Manajemen, 2(3), 1048:1057.

Wijaya, David. (2017). Manajemen Keuangan Konsep dan Penerapannya. Jakarta: Kompas Gramedia. 